\title{
PENERAPAN METODE PEMBELAJARAN TALKING STICK DALAM UPAYA MENINGKATKAN HASIL BELAJAR MATA PELAJARAN PKN KELAS VII-2 SMP NEGERI 3 KOTA TEBING TINGGI
}

\author{
Herlina Manurung \\ Surel: manurung.herlina@yahoo.com
}

\begin{abstract}
This purposes of this research is to improve learning result on civics subject through talking stick method. This classroom action researchconducted by 2 cycles of the four phases: planning, implementation, observation, reflection. The subjects were students from class VII-2 SMPNegeri 3Tebing Tinggi which amounted to 36 students. This study used a qualitative descriptive analysis technique. The results showed that the use of the inquiry method of civics subjects can improve student learning result characterized by increased mastery learning students, namely cycle I $(80,56 \%)$, cycle II $(88,89 \%)$ and complete learn the clasical equal to $88.23 \%$.
\end{abstract}

Key words: Talking stick, Civic, Learning outcomes

\begin{abstract}
ABSTRAK
Penelitian ini bertujuan untuk meningkatkan hasil belajar siswa mata pelajaran PKn melaui metode pembelajaran talking stick. Penelitian tindakan kelas ini dilaksanakan sebanyak 2 siklus dengan empat tahapan yaitu : perencanaan, pelaksanaan, observasi, refleksi. Subjek penelitian ini adalah siswa kelas VII2SMP Negeri 3Tebing Tinggi sebanyak 36 siswa.Penelitian ini menggunakan teknik analisis dekriptif kualitatif. Hasil penelitian menunjukkan bahwa penggunaan metodetalking stick pada mata pelajaran PKn dapat meningkatkan hasil belajar siswa yang ditandai dengan peningkatan ketuntasan belajar siswa, yaitu siklus I $(80,56 \%)$, siklus II $(88,89 \%)$,dan dinyatakan berhasil ssecara klasikal $88,89 \%$.
\end{abstract}

Kata Kunci : Talking stick, PKn, Hasil Belajar

\section{PENDAHULUAN}

Pembelajaran adalah suatu proses yang dilakukan individu untuk memperoleh suatu perubahan perilaku yang baru secara keseluruhan, sebagai hasil dari pengalaman individu sendiri dalam interaksi dengan lingkungannya. Dalam proses belajar mengajar sebaiknya dilaksanakan dengan melibatkan mental siswa secara individu secara maksimal, bukan hanya menuntut siswa untuk mendengarkan dan mencatat semua hal penjelasan dari guru dalam proses pembelajaran.

Pendidikan Kewarganegaraan merupakan mata pelajaran wajib pada semua satuan pendidikan dasar dan pendidikan menengah. Aspekaspekyang menjadi lingkup mata pelajaran ini, persatuan dan kesatuan bangsa, norma hukum dan peraturan, hak asasi manusia, kebutuhan warganegara, kekuasaan dan politik, pancasila, dan globalisasi (Depdiknas, 2007). Belajar adalah modifikasi atau memperteguh 
kelakuan melalui pengalaman (learning is defined as the modification or strengthening of behavior through experiencing). Belajar diartikan sebagai suatu proses, suatu kegiatan, dan bukan suatu hasil atau tujuan (Hamalik, 2011). Memiliki pemahaman dalam belajar merupakan hal yang sangat penting, sebab dengan pemahaman siswa bukan hanya mengerti dengan apa yang dipelajari tetapi juga mengingat apa yang dipelajari dalam jangka waktu yang lama. Pemahaman konsep sangat penting dengan tujuan agar siswa dapat mengingat konsep-konsep yang mereka pelajari lebih lama, sehingga proses belajar akan menjadi lebih bermakna (Santiasih, 2011).

Guru sebagai salah satu komponen dalam proses belajar mengajar memegang peranan yang sangat penting. Interaksi atau hubungan timbal balik antara guru dan siswa itu merupakan syarat utama bagi berlangsungnya proses pembelajaran. Seorang guru harus dapat memilih dan menerapkan model pembelajaran yang efektif agar materi yang dipelajari oleh siswa dapat dipahami dengan baik serta dapat meningkatkan hasil belajar. Selama ini pelaksanaan pembelajaran PKn di Sekolah dasar dianggap sebagai mata pelajaran yang membosankan. Hal itu terjadi dikarenakan adanya anggapan bahwa dalam proses belajar mengajar guru PKn sering kali masih menggunakan metode ceramah dan tanya jawab secara dua arah (two ways) secara dominan disbanding dengan metodemetode lain yang lebih bervariatif.

Masalah yang terjadi pada hasil belajar siswa kelas VII-2 SMP Negeri 3 Tebing Tinggi pada mata pelajaran PKn adalah rendahnya hasil belajar siswa.Hal ini dapat dilihat persentase ketuntasan belajar siswa masih 66,67\%. Kurikulum, proses pembelajaran, guru, siswa, sarana dan prasarana pembelajaran, serta interaksi sosial siswa di sekolah.Dari beberapa faktor tersebut, proses pembelajaran merupakan salah satu faktor yang paling penting. Jika proses pembelajaran berjalan baik dengan didukung oleh faktor penentu keberhasilan yang lainnya, maka akan menghasilkan anak didik yang bermutu sehingga dapat bersaing dalam era globalisasi.

Dari berbagai permasalahan yang muncul pada pembelajaran PKn di kelas VII-2 SMP Negeri 3 Tebing Tinggi dan mengakibatkan keterampilan guru, aktivitas siswa, serta hasil belajar PKn menjadi kurang maksimal, sehingga perlu adanya perbaikan kualitas pembelajaran.

Salah satu alternatif yang dianggap paling efektif dalam meningkatkan hasil belajar siswa adalahadalah dengan metode talking stick. "Metode Talking Stick mendorong peserta didik untuk berani mengemukakan pendapat" (Suprijono, 2009:109). Metode pembelajaran Talking Stick adalah metode pembelajaran yang pelaksanaan proses pembelajarannya 
dikelas berorientasi pada terciptanya kondisi belajar melalui permainan tongkat yang diberikan dari satu siswa kepada siswa yang lainnya.

Menurut Isjoni (2010), model pembelajaran talking stick merupakan pembelajaran kooperatif dimana dalam pembelajaran siswa membentuk kelompok untuk mempelajari topik tertentu, kemudian setelah berdiskusi siswa menutup buku. Selanjutnya setiap kelompok diuji oleh guru dengan menggunakan tongkat berjalan, kelompok yang mendapat tongkat, bertugas menjawab soal yang telah disiapkan guru.

Talking stick merupakan salah satu metode yang dapat digunakan dalam model pembelajaran inovatif yang berpusat pada siswa. Talking Stick adalah metode pembelajaran dengan bantuan tongkat, siapa yang memegang tongkat wajib menjawab pertanyaan dari guru setelah siswa mempelajari meteri pokoknya (Suryatno, 2009).

"Metode Talking Stick mendorong peserta didik untuk berani mengemukakan pendapat" (Suprijono, 2009:109). Hal ini tentu merupakan kelebihan yang dimiliki metode Talking Stick. Selain untuk melatih berbicara dalam mengemukakan pendapat, pembelajaran ini akan menciptakan suasana yang menyenangkan dan menjadikan siswa aktif.

Kelebihan dari metode talking stick ini menurut Sugiyanto (2010) adalah: 1) Meningkatkan kepekaan dan kesetiakawanan social, 2) Memungkinkan para siswa saling belajar mengenai sikap, keterampilan, informasi, perilakusosial, dan pandanganpandangan, 3) Memudahkan siswa melakukan penyesuaian social, 4) Memungkinkan terbentuk dan berkembangnya nilai-nilai sosial dankomitmen, 5) Menghilangkan sifat mementingkan diri sendiri atau egois, 6) Membangun persahabatan yang dapat berlanjut hingga masa dewasa, 7) Berbagai keterampilan sosial yang diperlukan untuk memelihara hubungan saling membutuhkan dapat diajarkan dan dipraktekkan, 8) Meningkatkan rasa saling percaya kepada sesama manusia, 9) Meningkatkan kesediaan menggunakan ide orang lain yang dirasakan lebih baik, 10) Meningkatkan kegemaran berteman tanpa memandang perbedaan kemampuan, jenis kelamin, normal atau cacat, etnis, kelas sosial, dan agama. Sedangkan kelemahan dari metode ini adalah Sangat tidak rasional kalau kita mengharapkan secara otomatis siswa dapat mengerti dan memahami filsafat Cooperative Learning. Untuk siswa yang dianggap memiliki kelebihan contohnya, mereka akan merasa terhambat oleh siswa yang dianggap kurang memiliki kemampuan. Akibatnya, keadaan semacam ini dapat mengganggu iklim kerjasama dalam kelompok.

Berdasarkan permasalahan tersebut maka penulis tertarik untuk meneliti metode ini karena 
stickmerupakan pembelajaran kooperatif dimana dalam pembelajaran siswa membentuk kelompok untuk mempelajari topic tertentu, kemudian setelah berdiskusi siswa menutup buku. Selanjutnya setiap kelompok diuji oleh guru dengan menggunakan tongkat berjalan, kelompok yang mendapat tongkat, bertugas menjawab soal yang telah disiapkan gurupada mata pelajaran PKn.

Tujuan dari penelitian ini adalah untuk meningkatkan hasil belajar PKn siswa kelas VII-2 SMP Negeri 3 Tebing Tinggi tahun pembelajaran 2016/2017 melalui metode pembelajaran talking stick.

\section{METODE PENELITIAN}

Penelitian ini diawali dengan pengajuan judul tentang penelitian yang akan dilaksanakan. Subyek penelitian adalah siswa kelas VII2SMP Negeri 3 Tebing Tinggi semester II tahun 2016/ 2017 dengan jumlah siswa sebanyak 36 orang dengan 16 orang laki-laki dan 19 orang perempuan. Sumber data yang digunakan adalah siswa dan teman sejawat.

Pada Penelitian tindakan kelas data yang dikumpulkan dapat berbentuk kuantitatif maupun kualitatif .Penelitian tindakan kelas tidak menggunakan uji statistik, tetapi dengan deskriptif.Data kuantitatif yang berupa nilai dianalisis dengan menggunakan analisis deskriptif komparatif yaiu membandingkan nilai tes kondisi awal, nilai tes setelah siklus I dan siklus II yaitu nilai dari hasil ulangan harian siswa kelas VII-2 SMP Negeri 3 Tebing Tinggi pada siklus I dan II.

Komponen pengajaranstrategi pembelajaran talking stick yang sangat data kualitatif yang berupa observasi kegiatan guru, dan sisa serta data kuantitatif yang berupa nilai hasil ulangan harian siswa kelas VII-2. Model penelitian tindakan kelas yang digunakan peneliti adalah system spiral refleksi diri yang dikembangkan oleh Kemmis dan Taggart (1990: 11) yang dimulai dengan perencanaan, tindakan, pengamatan, dan refleksi. Masingmasing siklus terdiri dari dua kali pertemuan yaitu sebagai berikut:

\section{Perencanaan}

Sebelum mengadakan penelitian peneliti menyusun rumusan masalah, tujuan dan membuat rencana tindakan, termasuk di dalamnya menetapkan standar kompetensi dan kompetensi dasar, RPP, LKS, instrumen penelitian dan perangkat pembelajaran.

\section{Pelaksanaan}

\section{Siklus I}

Pada tahap ini, rencana pembelajaran yang telah disusun oleh guru bersama peneliti dipergunakan sebagai dasar dalam menyelenggarakan pembelajaran. Dalam pelaksanaan tindakan. Kegiatan inti pada pelaksanaan ini adalah Mempresentasikan langkahlangkah metode pembelajaran talking stick, menyampaikan materi pokok yang akan dipelajaran, Memberikan 
Herlina Manurung: Penerapan Metode Pembelajaran...

tongkat kepada siswa dan menyalakan music, dan Memberikan pertanyaan kepada siswa yang mendapatkan tongkat saat musik berhenti.

Pada saat kegiatan pembelajaran berlangsung guru sebagai peneliti dibantu oleh para observer lainnya untuk melakukan pengamatan, pen-dokumentasian, selain itu peneliti bertindak sebagai fasilitator, motivator dan sekaligus sebagai pengamat.

\section{Siklus II}

Guru melakukan pembelajaran didalan kelas dengan menggunakan panduan perencanaan yang telah dibuat dengan RPP dan seperti pada siklus I dengan materi yang berbeda namun ke arah yang lebih baik. Kekurangan pada siklus I diperbaiki pada siklus II. Pada Siklus kedua ini juga, suasana pembelajaran masing-masing kelompok di lingkungan sekolah dikondisikan agar tidak terlalu formal, maksudnya siswa bebas mengemukakan pendapatnya tentang materi ajar sesuai dengan kompetensi dasar yang ingin dicapai.

\section{Observasi/Pengamatan}

$$
\text { Pengamatan dilakukan }
$$

peneliti sendiri dan dibantu oleh pengamat dan mencatat proses penerapan teknik pengajaran kolaborasi. Dalam pelaksaan observasi atau lembar cheklist yang berisi tindak mengajar guru dan tindak belajar siswa, selain itu menggunakan dokumentasi berupa foto-foto kegiatan pembelajaran berlangsung, pada tindak mengajar guru sudah bagus menyampaikan pembelajaran sesuai RPP yang telah dibuat, pada tindak belajar siswa sudah aktif dalam mengungkapkan pendapat dan bekerja sama dengan kelompoknya.

\begin{tabular}{|c|c|c|}
\hline Refleksi & & \\
\hline Pelak & anaan & refleksi \\
\hline merupakan & hasil & observasi/ \\
\hline pengamatan & peneliti & pada \\
\hline nelakukan & observasi & kelas \\
\hline
\end{tabular}
maupun di lingkungan sekitar sekolah yang bertujuan untuk mengevaluasi hasil tindakan yang telah dilakukan.Kegiatan pada tahap refleksi meliputi kegiatan menganalisis, memahami dan membuat kesimpulan berdasarkan hasil observasi setiap siklus.Menemukan kelebihan dan kelemahan tindakan perbaikan pembelajaran. Hasil analisis data yang dilaksanakan pada tahap ini akan dipergunakan untuk menemukan kelebihan dan kelemahan diri dalam merancang dan melakukan tindakan sebagai acuan.

Penelitian ini dapat dikatakan berhasil dan tidak perlu dilanjutkan kepada siklus berikutnya apabila hasil dari tes siswa yang berjumlah 36 orang telah sesuai dengan KKM yang ditentukan yaitu 70 atau tingkat ketuntasan kelas diatas $85 \%$.

\section{HASIL PENELITIAN DAN PEMBAHASAN}

$\begin{array}{rr}\text { Hasil penelitian } & \text { tindakan } \\ \text { kelas menunjukkan } & \text { bahwa }\end{array}$ 
pengamatan yang dilakukan oleh peneliti yang dibantu dengan mitra kolaborasi pada aktivitas guru dan siswa melalui penerapan metode talking stick pada mata pelajaran PKndi kelas VII-2 SMP Negeri 3 Tebing Tinggi dapat dilihat pada Tabel 1 yaitu sebagai berikut:

\section{Tabel 1. Peningkatan Hasil Belajar} Siswa Siklus I dan II

\begin{tabular}{c|c|c|c}
\hline \multirow{2}{*}{$\begin{array}{c}\text { Keterang } \\
\text { an }\end{array}$} & \multicolumn{3}{|c}{$\begin{array}{c}\text { Peningkatan Hasil } \\
\text { Belajar }\end{array}$} \\
\cline { 2 - 4 } & $\begin{array}{c}\text { Pra } \\
\text { siklus }\end{array}$ & Sikus I & $\begin{array}{c}\text { Siklus } \\
\text { II }\end{array}$ \\
\hline $\begin{array}{c}\text { Nilai } \mathrm{x}- \\
\text { ulangan } \\
\text { harian }\end{array}$ & 70,5 & 73,8 & 74,7 \\
\hline $\begin{array}{c}\text { Jumlah } \\
\text { Siswa } \\
\text { Tuntas }\end{array}$ & 24 & 29 & 32 \\
\hline $\begin{array}{c}\text { Persen } \\
\text { Ketuntasa } \\
\text { n Belajar } \\
(\%)\end{array}$ & 66,67 & 80,56 & 88,89 \\
\hline
\end{tabular}

Berdasarkan pengamatan peneliti dari tindakan pra siklus, siklus I dan siklus II pada Tabel 1 terjadi peningkatan hasil belajar pada jumlah siswa dan persen ketuntasan belajar secara klasikal. Hal ini dapat dilihat dengan peningkatan jumlah siswa dari 24 siswa yang tuntas belajar pada pra siklus menjadi 32 siswa yang tuntas belajarpada sikus II. Terjadi peningkatan nilai ulangan rata-rata pada siswa melalui metode pembelajaran talking stick pada siswa kelas VII-2 SMP Negeri 3 Tebing Tinggi.
Pada siklus I nilai rata-rata hasil belajar siswa adalah 73,57 dan ketuntasan belajar mencapai 79,41\% atau ada 29 siswa dari 36 siswa sudah tuntas belajar. Hasil tersebut menunjukkan bahwa pada siklus pertama secara klasikal siswa belum tuntas belajar, karena siswa yang memperoleh nilai $\geq 70$ hanya sebesar $80,56 \%$ (belum tuntas) lebih kecil dari persentase ketuntasan yang dikehendaki yaitu sebesar $85 \%$.

Pada siklus I, secara garis besar kegiatan belajar mengajar dengan metode pembelajaran talking stick sudah dilaksanakan dengan baik, walaupun peran guru masih cukup dominan untuk memberikan penjelasan dan arahan, karena model tersebut masih dirasakan baru oleh siswa.Siswa belum terbiasa untuk berdiskusi dan menyampaikan argumennya serta menaggapi pertanyaan lawan bicara terhadap materi yang dibahas dan hanya mengandalkan temannya yang pintar. Namun secara umum proses pembelajaran berlangsung seperti yang direncanakan.

Siswa pertama kali melaksanakan metode ini gugup karena siswa masih merasa takut dengan pertanyaan yang secara langsung di lemparkan kepada siswa, pada saat tongkat dilempar siswa semangat dengan bernyanyi lagu balon ku ada lima dan pada saat tongkat berhenti pada salah satu siswa kebanyakan siswa merasa takut jawabannya yang salah atau kurang tepat, dan guru selanjutnya memberi pertanyaan kepada masing- 
Herlina Manurung: Penerapan Metode Pembelajaran...

masing siswa sampai semua siswa mendapat giliran pertanyaan dan begitu seterusnyaMaka dari itu dilanjutkan ke siklus kedua. Aspekaspek yang dianggap kurang baik pada siklus pertama akan direfleksi untuk dijadikan perbaikan pada siklus selanjutnya.

Pada siklus II, diperoleh nilai rata-rata hasil belajar siswa adalah 74,7 dan ketuntasan belajar mencapai $88,89 \%$ atau ada 32 siswa dari 36 siswa sudah tuntas belajar. Hasil tersebut menunjukkan bahwa pada siklus kedua secara klasikal siswa sudah tuntas belajar, karena siswa yang memperoleh nilai $\geq 70$ sebesar $88,89 \%$ lebih besar dari persentase ketuntasan yang dikehendaki yaitu $\geq$ sebesar $85 \%$. Dalam hal ini siklus II sudah memenuhi kriteria ketuntasan belajar dengan metode talking stick.

Pada siklus II, secara garis besar kegiatan belajar mengajar dengan metode pembelajaran talking stick dilaksanakan dengan cukup baik. Keterampilan guru, aktivitas siswa dan hasil belajar siswa mengalami peningkatan yang signifikan. Aktivitas siswa yang dominan adalah mendengarkan /memperhatikan penjelasan guru. Sudah mulai ada komunikasi dan kerjasama yang cukup baik antara guru dan siswa, karena masingmasing siswa sudah mulai bias menghilangkan beban rasa malu, gugup dan takut salah dalam menjawab pertanyaan. Mayoritas dari mereka sudah mulai terbiasa dengan model pembelajaran yang guru terapkan. Ditambah lagi pada siklus II ini, guru berusaha memberikan pujian pada beberapa siswa atas prestasi yang diraih, dengan itu maka akan menjadi penyemangat bagi siswa lain yang belum pernah mendapatkan pujian dari guru.

Siswa tampak bersemangat dalam menjawab pertanyaan dan menyelesaikan tugas yang diberikan oleh guru.mereka saling membantu memahami materi yang diberikan. Mereka saling melontarkan pertanyaan demi tercapainya hasil belajar yang memuasakan.serta menampakkan rasa gembira dan senang selama mengikuti pembelajaran. Tidak tampak rasa letih dari roman muka mereka, bahkan ketika peneliti memberi kesempatan untuk mengajukan pertanyaan, dengan serentak para siswa berebut bertanya kepada guru, sehingga tidak sia-sia peneliti menggunakan metode talking stick untuk meningkatkan aktivitas belajar siswa. Karena siswa sudah berani menjawab pertanyaan guru.

Dalam proses pembelajaran ini para peserta didik akan mengalami proses pembelajaran yang mereka rasa sangat menyenangkan. Suasana belajar yang biasa mereka rasakan sehari-hari yang sangat membosankan akan berubah menjadi suasana belajar yang sangat berbeda dan menyenangkan. Karena semua peserta didik akan diajak bermain dan belajar yakni dengan bernyanyi dan menjawab pertanyaan. Akan tetapi dalam proses pembelajaran ini 
peserta didik harus dapat menguasai materi dengan baik agar tidak kesulitan dalam menjawab pertanyaan.

Kegiatan pembelajaran talking stick memberikan pengaruh positif terhadap suasana pembelajaran di kelas, yaitu menimbulkan suasana yang aktif, menyenangkan dan kompetitif. Dengan terciptanya suasana pembelajaran yang seperti itu, tentunya dapat menciptakan pembelajaran PKn yang lebih efektif. Penerapan pembelajaran talking stick membiasakan siswa untuk bertindak aktif mencari jawaban dari sebuah masalah, belajar memahami sesuatu dengan cepat tanpa menghapal, dan meningkatkan kepercayaan diri siswamelalui komunikasi secara lisan di depan umum.

Pemahaman siswa tentang konsep-konsep PKn akan semakin meningkat dengan mengikuti pembelajaran metode talking stick, karena dalam metode talking stick siswa terus diuji dengan diberikan pertanyaan-pertanyaan yang dapat menggali pengetahuan siswa tentang konsep yang telah ia pelajari. Hal ini sependapat dengan pernyataan Suryatno (2009), talking Stick adalah metode pembelajaran dengan bantuan tongkat, siapa yang memegang tongkat wajib menjawab pertanyaan dari guru setelah siswa mempelajari meteri pokoknya. Selain itu Suprijono (2009) juga menyatakanmetode talking stick mendorong peserta didik untuk berani mengemukakan pendapat"
Metode pembelajaran talking stick adalah metode pembelajaran yang pelaksanaan proses pembelajarannya dikelas berorientasi pada terciptanya kondisi belajar melalui permainan tongkat yang diberikan dari satu siswa kepada siswa yang lainnya.

\section{Pembahasan}

Berdasarkan hasil yang didapat dari setiap siklus proses pembelajaran yang optimal, hal ini ditunjukkan dengan meningkatnya penguasaan materi dan hasil belajar siswa. Peningkatan kualitas pembelajaran dan dampaknya terhadap kemampuan berbicara siswa ini erat kaitannya dengan kemampuan Guru menggunakan metode talking stick dalam penyajian materi. Oleh karena itu dapat disimpulkan bahwa proses pembelajaran dengan penerapan metode talking stick sangat sesuai dengan mata pelajaran PKn.

Maka dari itu, Penelitian Tindakan Kelas (PTK) ini bisa dikatakan berhasil karena hasil peningkatan proses pembelajarannya optimal.

\section{SIMPULAN}

Dari hasil penelitian yang dilakukan tentang hasil belajar siswa dengan metode talking stick di kelas VII-2 SMP Negeri 3 Tebing Tinggi tahun pelajaran 2016/2017 bahwa metode talking stick berdampak positif dalam meningkatkan hasil belajar Pkn. Hal tersebut dapat dilihat dari peningkatan persentase ketuntasan belajar siswa pada pra 
Herlina Manurung: Penerapan Metode Pembelajaran...

siklus $(66,67 \%)$, siklus I $(80,5 \%)$

dan siklus II $(88,89 \%)$.

DAFTAR RUJUKAN

Departemen Pendidikan Nasional. 2007. Standar Isi untuk SD/MI. Jakarta: Depdiknas

Hamalik, Oemar. 2011. Proses Belajar Mengajar. Jakarta: Bumi Aksara.

Isjoni. 2010. Cooperative Learning. Bandung: Alfabeta.

Santiasih, Ni Made. 2011. Pengaruh Model Siklus Belajar 7E Terhadap Keterampilan Berfikir Kritis dan Pemahaman Konsep Siswa Dalam Pembelajaran Fisika Kelas X SMA Negeri 1 Gianyar Tahun Pelajaran 2010/2011. Skripsi (tidak diterbitkan). Universitas Pendidikan Ganesha.

Suprijono, Agus. 2009. Cooperative Learning Teori dan Aplikasi PAIKEM. Yogyakarta: Putaka Belajar

Suyatno. 2009. Menjelajah

Pembelajaran Inovatif.

Sidoarjo: Masmedia Buana

Pustaka. 